\title{
The Cyrurgia of Albucasis and other works, 1500
}

Four surgical treatises, printed in the last year of the fifteenth century, make up the oldest illustrated printed book in the Sibbald Library.' The second one, the Cyrurgia of Albucasis, is the most interesting and I shall deal only briefly with the others.

The first work in the book, Cyrurgia parva Guidonis, is the Chirurgia parva or short treatise on surgery of Guy de Chauliac, a fourteenth-century French surgeon whose works were still influential in the sixteenth century. His work was heavily influenced by Arab sources and became a standard surgical text which was reworked many times and appears in many forms in the sixteenth century, often with the title Guido or Guidon. Here, however, we have the first printed Latin edition of the Chirurgia parva, a brief compendium of the Chirurgia magna of (probably) I363. It seems likely that the Chirurgia parva is a series of extracts made from the larger work by an unknown hand or hands.

The third and fourth treatises, Tractatus de oculis Jesu hali and Tractatus de oculis Canamusali, concern the eye and their authorship is somewhat obscure. Jesu Hali (Jesus filius Hali) was the Latinised name of Ali Ben Isa who flourished around 1050 and wrote on the eye.

Canamusali de Baldach would appear to be Ammar ibn Ali al-Mausili who probably hailed from Mosul rather than from Baghdad as his Latinised name would suggest; if so, he probably flourished in the thirteenth century. In this text, he presents himself as collator rather than author, saying clearly that he has made a compendium of material on the eye from various 'Hebrew and Chaldean sources and from India'. Hargreaves regards the attribution of the text which Canamusali presents as doubtful but suggests David the Armenian (David Armenicus) as the possible author. ${ }^{2}$ Sack simply attributes it to David Armenicus. ${ }^{3}$ Perhaps the only safe conclusion is that these two works on the eye contain a collection of material from mediæval Arabic sources.

The second treatise in the collection, Cyrurgia Albucasis cum cauteriis et aliis instrumentis, is of much more interest than the others for several reasons. The work on surgery of Abu 'I-Qasim Khalaf ibn 'Abbas al-Zahrawi (936I0 I3), Latinised as Albucasis or Abulcasis, was a standard mediæval text which has some claim to be the first complete surgical treatise. Albucasis was an Andalucian Moor who spent most of his life in Cordoba and published his treatise about the year 1000. The Arabic text was translated into Latin by Gerard of Cremona in the twelfth century. The attribution to Gerard in this edition depends on the explicit at the end of the work (Figure 1): 'The end of the book on surgery which was translated by Master Gerard of Cremona at Toledo from Arabic into Latin; this book comes from the $\mathbf{3 0}$ individual books of the acaragi written by Albucasis.'

The Latin translation of Albucasis's three-part surgical treatise became the most popular surgical text of the Middle Ages and, until the Renaissance, writers including Guy de Chauliac were heavily influenced by it. The Arabic manuscripts of the treatise were illustrated with numerous diagrams of the surgical instruments which are described, sometimes in considerable detail, in the text. These illustrations were presumably copied into the Latin translation when this was made. Thus text and illustrations were transmitted together and it must be from such an illustrated Latin manuscript that the type was set and the woodblocks drawn and cut for the illustrated printed editions.

There has been confusion in the literature about the date of the first printed edition of Albucasis on surgery; in fact, there is no doubt that this printed edition of $1500 / 0 \mid$ is the first, as an examination of the British Library Incunabula Short Title Catalogue confirms." The publication date of $|500 / 0|$ derives from the date in the colophon: 'M.CCCCC. Sexto Kal. Februarias', which is 27 January in modern notation; however, the Venetian numbered year did not begin until I March at this period - hence the Venetian year is 1500 , but the year would be I50I if reckoned from I January.

The treatise is particularly interesting for at least two quite different reasons; firstly, for its content, including the illustrations and descriptions of the instruments. Secondly and perhaps more importantly, this book is also a very early example of the use of woodcut illustrations embedded in the text. The printing surface of a woodblock stands in relief as does that of metal type. This means that the block can be placed among the lines of metal type -

CExplicit liber cyrurgie quê träftulitmagr̃ §erard"creı monenfis in tolleto oearabico in latinü: $q$ liberé tricefi, ma pticula libzi açaragi: qué ppofuit zalbucafim.

FIGURE I The end of the last (third) book of Albucasis's surgical treatise with the attribution of the translation to Gerard of Cremona. 
indeed, the lines of type can be made to flow around it and, provided the height of the block is carefully adjusted, its image can be printed along with the image of the letterpress in the same pull of the hand press. This ability to print letterpress and type together gives the compositor or designer the possibility of arranging the illustrations so that each is close to the text it illustrates.

This was a new innovation in printed book illustration, although it had been common enough in some earlier manuscript practice. Probably the most accomplished use of this arrangement of woodcuts in the sixteenth century is the Fabrica of Vesalius. This Albucasis predates the Fabrica by 43 years. The bibliographer HG Aldis is disparaging of Bonetus Locatellus, the printer of the four surgical treatises, 'whose books are more numerous than interesting', ${ }^{4}$ but if Locatellus or the publisher for whom he printed the treatises, Octavian Scot of Modena, was the first to devise this arrangement of woodcut and text, that judgement is more than unjust. In any case, whether it was his invention or not, Locatellus's workmen made a fine job of the printing; both images and text are clear - even if sometimes the solid black regions of some images are not as uniform as they should be which speaks of precise adjustment of the blocks and careful presswork.

Turning now to the content, the scholarly English edition of Spink \& Lewis ${ }^{5}$ giving the Arabic text collated from a number of illustrated manuscripts together with an English translation and commentary means that we can compare both the content of the text and the illustrations between an Arabic mediæval version and the translation of Gerard as printed here. The French translation of I86I from the Arabic by Lucien Leclerc, an army doctor, is also very valuable for these comparisons. ${ }^{6}$ The correspondence is remarkably close indicating that, in this case at least, the transmission from Arabic into Latin and over $\mathbf{5 0 0}$ years preserved both text and images. The versions of the images that were passed down still correspond very well with the descriptions both of the instruments and of their use.

The first book is concerned only with the illustration and use of cautery irons and is, for me at least, much less interesting than the second two books which deal with a wide range of surgical conditions - and conditions treated surgically (not the same thing), including abscesses, wounds, fractures, 'dropsy' and various gynaecological conditions and obstetric complications. Some modern commentators have claimed that Albucasis used forceps to assist delivery, pre-dating the Chamberlens by more than half a millennium, but the work contains no evidence to support this. The obstetrical instruments are all illustrated and described in a chapter on removing the dead fetus and they are clearly quite unsuitable for use on a living child (for discussion of these instruments see reference 5, p. 488-94).

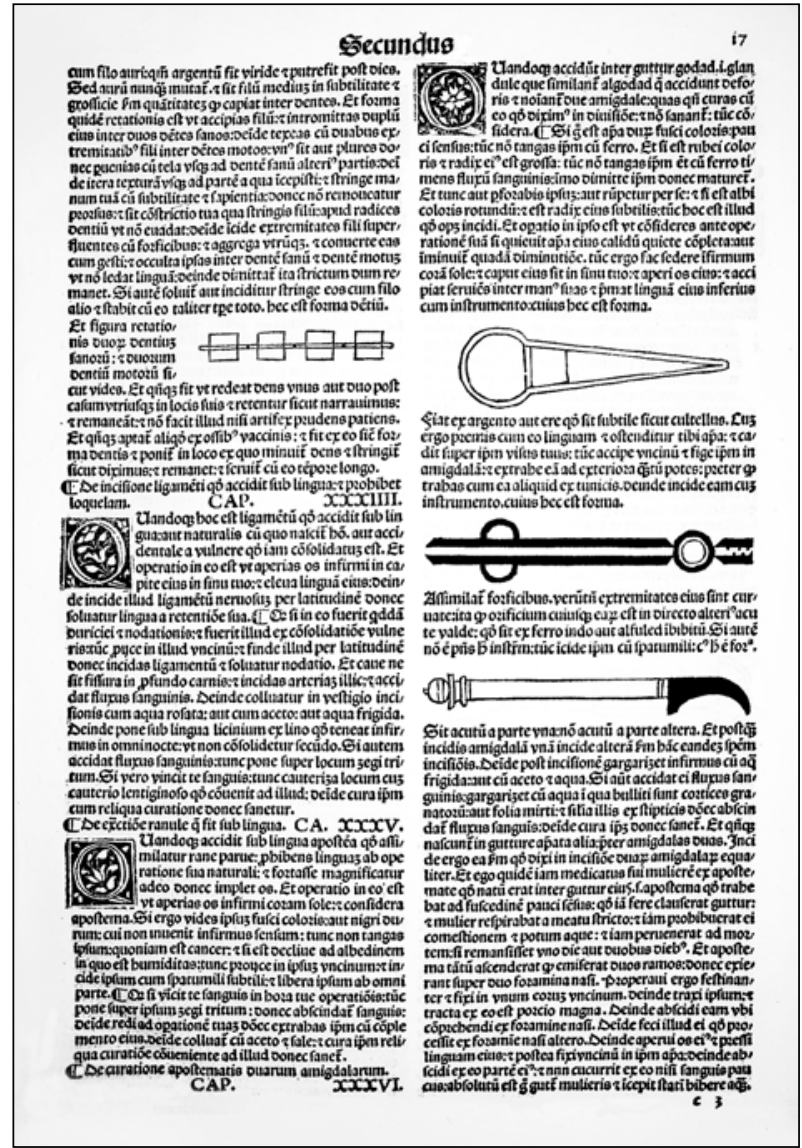

FIGURE 2 A page from Book II of Albucasis on surgery. Note the decorated capitals and illustrations printed from woodblocks. On the left is an illustration of teeth wired together; see Figure 3. The text flows round the figure which is placed just beside the description of the procedure. On the right are three instruments for use in tonsillectomy; see Figure 4.

Space allows only brief descriptions here of two of Albucasis's accounts of his procedures.

\section{REPLACING TEETH}

Albucasis describes a number of dental procedures; here is his account of the treatment of loose or missing teeth. He first describes how, if medical treatment has been unsuccessful in fixing loose teeth, they should be wired to sound teeth on either side using silver or, preferably, gold wire since the latter does not corrode. The wire is to be looped around a sound tooth, then woven in and out around the loose teeth until it is wrapped round another sound tooth. The figures in the Arabic manuscripts show this weaving more clearly than does Figure 2. Translating from Et figura we have:

And here is the illustration of fixing two loose teeth between two sound ones, as you can see. And if one or two of the teeth should fall out, put them back in place and fix them as we have instructed and they will stay in place; but this is not to be attempted except by a painstaking and skilled surgeon. And 
manet. F́ iautè foluit aut inciditur ftringe euscaun filo alio z ftabit cí eo taliter tpe toto. bec eft forma oétiü. Et figlira retatio,

nis ouly oentiuz

Ianozu: : oulozum

oentiú motozí fi,

cut vides. Et quiq 3 fit vt redeat oens vnus aut ouo poft

cafumvtriufqz in locis fuis z retentur ficut narrauimus:

z remaneăt:z nó facit illud nifi artifexpudens patiens.

Et quĩq 3 aptaṫ aliqỏ croffib' vaccinis: $z$ fit ex eo fič for,

ma oentis z poniť in locoexquo minuit ocns z ftringit

ficut oiximus:z remanet: $z$ feruiť cü eo tèpozelongo.

FIGURE 3 Enlarged view of image on left of Figure 2 and part of the description of wiring loose to sound teeth.

sometimes a piece of ox bone may be worked into the shape of a tooth and fitted into the place of a [missing] tooth and fixed there as we have directed; it will remain in place and [the patient] will have the use of it for a long time.

This must be judged an impressive account of dental treatment for around the year 1000; one wonders how many 'painstaking and skilled' surgeons were able to achieve these long-lasting results.

\section{TONSILLECTOMY}

Albucasis is said to have been the first to describe a special instrument for tonsillectomy, an operation he describes in some detail. It is worth considering part of his account in some detail. He begins by advising that what were probably suppurating tonsils should not be operated on and that the operation should be delayed until acute inflammation has settled; the description of the operation proper begins on the first line of the text in Figure 4.Translating the text from $t u[n] c$ ergo we have:

Sit the patient facing the sun with his head in your lap; open his mouth and let an assistant hold [the patient's head] between his hands and depress his tongue with the instrument drawn here [top drawing]. Let it be made of silver or bronze and as thin as a small knife blade. Then when you press the tongue down with it the swelling will be apparent and your gaze will fall upon it. Then take a hook and fix it in the tonsil and pull it as far forward as possible but avoid pulling any of its capsule [adjacent mucosa?] with it. Then cut it off with the instrument drawn below [middle drawing] which is similar to a forceps except that its ends are curved with each hollow exactly opposite its fellow, and extremely sharp. It is made of Indian iron or alfuled inbibitum.*

But if you do not have such an instrument cut the tonsil off with a knife of this kind [bottom drawing] which is sharp only on one side. When you have removed one tonsil, remove the other using the tiic ergo fac federe ifirmum cozã fole: zcaput eius fit in fint tu!o:z apcri os cius: zacci piat fertiēs inter man' fuas $z$ p mat linguã cius inferiug cum inftrumento:cuitus bec eft forma.

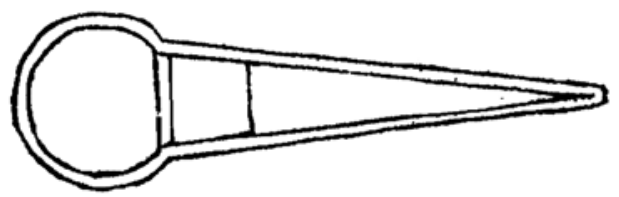

Siat exargento aut erc $q \delta$ fit fubtile ficut cultellus. Lus crgo pzemis cum eo linguam zoftciditur tibiaja: zca dit fuper ipm vifus tuus: tric accipe oncinu 2 fige ipm in

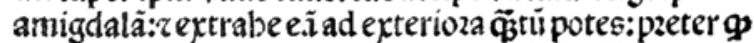
trabas cum ea aliquid ex tunicis. oende incide eamcuz inftrumento.cuius bec eft forma.

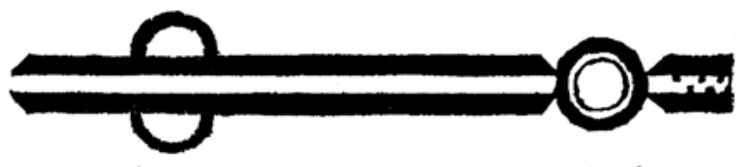

Affimilat forficibus. verütũ extremitates eitı fint cur, uate:ita 9 ouficium cuiuf́r eapy eft in oirecto alteri?acu te valde: qó fit ex ferro indo aut alfuled ibibitu. Fiaute

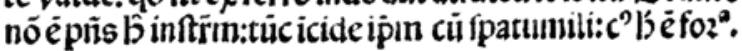

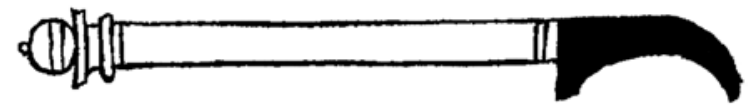

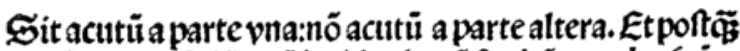
incidis amigdalã vnã incidealterã f̂m bäceandes $\{$ pém

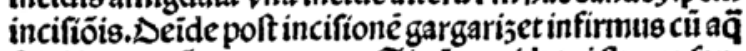
frigida:aut cú aceto zaqua. Fi aüt accidat ei fluxus fan' guinis:gargarizet cũ aqua i qua bulliti funt coztices gra, natozù:aut folia inirti:z fituaillis efftipticis oóec abfcin dat fluxus fanguis:oeidecura ip̃ 5 oonec fanet. Et quís

FIGURE 4 Instruments for and part of the description of tonsillectomy. From top down: tongue depressor, cutting forceps or guillotine (the cutting jaws are at the right) and a curved knife sharp only on its concave edge.

same type of incision then let the patient gargle with cold water or vinegar and water. If there should be haemorrhage make him gargle with water in which pomegranate rind or myrtle-berries have been boiled and continue with styptics until the bleeding ceases then treat him until it is healed.

Although the general nature of the procedure is clear enough, if we imagine trying to follow the directions in detail we soon find that we could not do as the text instructs. We are to put the patient coram sole presumably so that the sun shines on his face - with his head in sinu tuo; just what does this mean? 'In your lap,' as Spink \& Lewis say translating from the Arabic, or 'on your knees', as Leclerc has it, also from the Arabic? An assistant is then to hold the patient's 'head between his two hands', but then the assistant is also to depress the tongue; how? - his hands are full. Next, we are told that we (the surgeon) are to depress the tongue, but apparently the assistant has already done that while also using both hands to hold the patient's head. While we 
depress the tongue we are to fix a hook in the tonsil, which uses our free hand. Then we are to take the 'guillotine' to cut the tonsillar pedicle, but this is not possible since both our hands are already occupied. In short, we cannot carry out the operation like this.

Assuming that it was possible to carry out tonsillectomy at the time (and Albucasis has apparently designed a special instrument for the operation), what has gone wrong with our text? Perhaps Gerard of Cremona mistranslated the Arabic? But it seems that cannot be the whole explanation since Leclerc also gives an impossible set of instructions. However, Spink \& Lewis do not require the assistant to hold the head or the surgeon to depress the tongue so their instructions are practicable, suggesting that there is probably some difficulty in interpreting the Arabic text. However, there does exist a much older description of the operation whose directions it certainly would be possible to follow, that of Paul of Aegina (Paulus Aegineta), a seventh-century Byzantine Greek whose work was certainly known to Albucasis and influenced him. ${ }^{7.8}$ Here, translating from Alban Thorer's Latin, is what the surgeon is to do:

We set the patient facing the light of the sun, with his mouth wide open and an assistant holding the back of his head and with a second [assistant] depressing his tongue towards the mandible with a spatula designed for this purpose; we take a hook and push it into the tonsil which we pull forwards without breaking its capsule. Then we amputate the structure through its pedicle with a scalpel with the blade curved for use by that hand - for there are two of these with their blades oppositely curved.

\section{REFERENCES}

I Cyrurgia parva Guidonis. Cyrurgia Albucasis cum cauteriis \& aliis instrumentis. Tractatus de oculis Jesu hali. Tractatus de oculis Canamusali. Venice: Bonetus Locatellus; 1500.

2 Hargreaves GD. A catalogue of medical incunabula in Edinburgh libraries. Edinburgh: Royal Medical Society; 1976. p. 52.

3 Sack V. Die Inkunabeln der Universitätsbibliothek und anderer öffentlicher Sammlungen in Freiburg im Breisgau und Umgebung. Part I.Wiesbaden: Harrassowitz; 1985. p. I,688.

4 Aldis HG. The printed book. 2nd ed. Cambridge: Cambridge University Press; 1921. p. 14.

5 Spink MS, Lewis GL, editors. Albucasis on surgery and instruments. London:Wellcome Institute of the History of Medicine; 1973.

6 Leclerc L. La chirurgie d'Abulcasis. Paris: JB Baillère; 186I. p. 106.

7 Aegineta P. De re medica libri septem. Trans. A Thorer. Basel: Andreas Cratander; 1538. p. 370.

8 Adams F, editor. The seven books of Paulus Ægineta. Trans. F Adams. Vol II. London: Sydenham Society; I846. p. 297.

\section{NOTES}

The images illustrating this paper have been digitally enhanced and retouched to improve their contrast and legibility.

* Confusingly, there were two Gerards of Cremona. The first (fl. twelfth century) translated works on philosophy. The second, also known as Gerard de Sabloneta (fl. thirteenth century), is credited with translating Avicenna and Rhazes and may have translated Albucasis.

$\dagger$ The name of the Arab work acaragi is unclear, but the Kitab-al Tasrif apparently did have 30 volumes or parts and there is no doubt that
What could be clearer? Adams's translation from Greek confirms the account in every detail. Since Paul also gives identical advice to that of Albucasis about when not to operate and about other details, we may suspect that the rather confused instructions now credited to Albucasis are a distorted version of Paul's account or an account based on his. Albucasis may have invented a better instrument to cut the tonsillar pedicle, but that seems to be all he contributed to tonsillectomy.

If this analysis of a tiny portion of a large work teaches us only one thing it should be that, if a text demands the impossible, it is most probably corrupt. But perhaps it also makes it easier for us to understand why Renaissance scholars were so anxious to seek out 'ancient' sources not just because of their chronological age but because they hoped they were nearer to an accurate account of the writings of their revered masters, distorted by fewer passages through endless copies of copies, each risking the introduction of new errors. And that, in turn, should remind us that printing revolutionised the transmission of texts not only by making multiple copies available relatively inexpensively, but also by making it possible for many readers to consult identical material with much greater ease and, when they became available, for the 'best' versions of ancient texts to be made (almost) universally available. With the increase over the sixteenth century in the number of texts translated into vernaculars, this became even more important.

IML Donaldson, Honorary Librarian, RCPE (email: i.m.l.d@ed.ac.uk)

it is the work in question. It is the 30th volume or part of Albucasis's treatise, that on surgical instruments. ${ }^{5}$ See also ** below.

II One of Albucasis's other works, the Liber servitoris, was printed by Jenson in Venice in 147I, which has apparently confused some authors. Surprisingly, Spink \& Lewis who write, correctly, that the surgical work was first printed with Guy de Chauliac's Cyrurgia Parva, date this to $1497,{ }^{5}$ but the Albucasis in this book is also Liber servitoris, and they claim further editions in 1499 and I500. I can find no trace of 1497 or 1499 editions containing the surgical treatise and the I500 is our edition. However, there is a I499 edition of Guy de Chauliac's Chirurgia (magna) which also contains the treatises De oculis of Canamusali and Jesus filius Hali; one copy of the Bodleian Library's Cyrurgia parva (I500), which contains the surgical treatise, is bound with this. Perhaps this was one source of confusion.

** When the mediæval translators did not understand a word in the Arabic manuscript or could not find a Latin translation for it, they sometimes attempted a phonetic transliteration which is generally obscure to the non-Arabic reader; alfuled is an example. Inbibitum is genuine Latin but is meaningless without knowing the preceding word.We have a Latin translation of 1533 which replaces these two words with aut simili cauterio '[metal] similar to that used for a cautery', which at least makes sense. The French translation ${ }^{6}$ from the Arabic gives a clue that allows us to make sense of alfuled inbibitum. A footnote to the phrase fer de Damas says that a word transcribed as foulad means hardened steel or iron (acier or fer trempé). One can imagine foulad being rendered by the translator as alfuled in which case inbibitum makes perfect sense since it can mean soaked - as does the French trempé - meaning here the quenching of hot steel to harden it. 


\section{ZAlbucafig}

Sozma impellentis quio impellitur fetuo.

Q1)

Sorma almifdac qua oteritur caput magnũ: ₹affimilaț rozpici:cui funt oétce in cxtremitate ficut vidco. Et quí fit oblungum ficut forpices ofm banc formas ficut vides cui funt oétes ficut oentce ferre quo incidiế a pterif́.

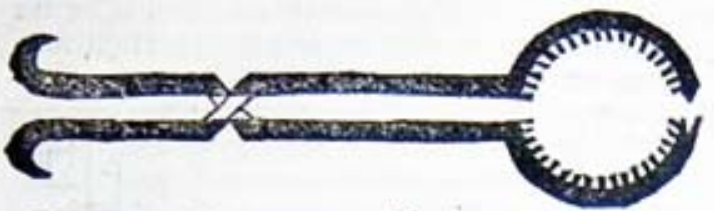

Sorma almifdacquo conterif̈ caput partun.

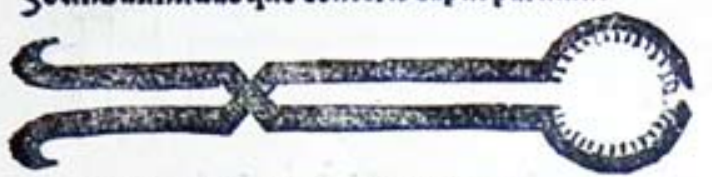

§ozma yncinibabentis fpinam vnam.

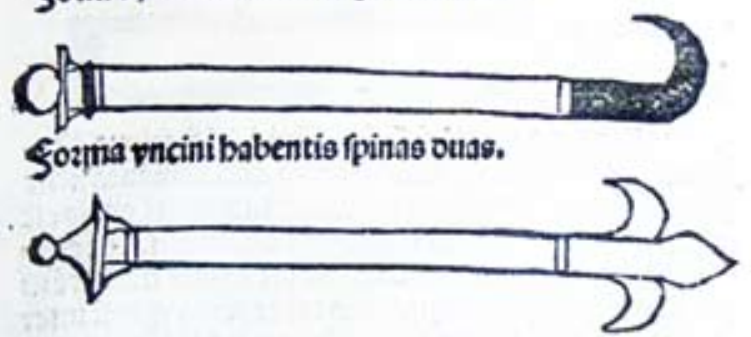

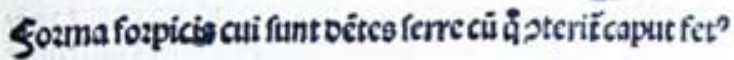

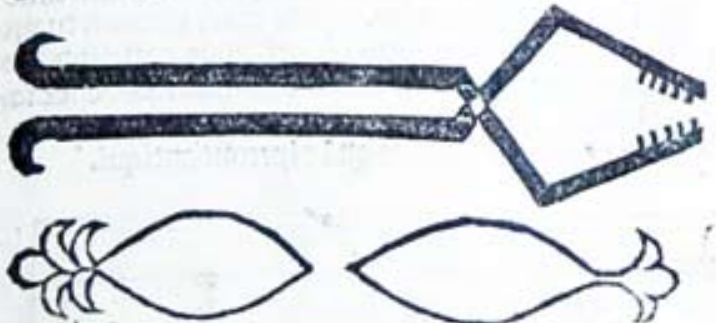

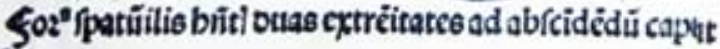

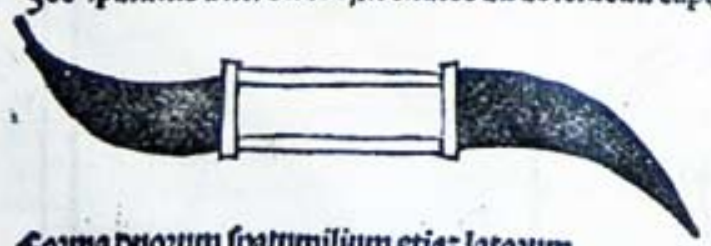

Gorma ouozum fpatumilium etios latoum.

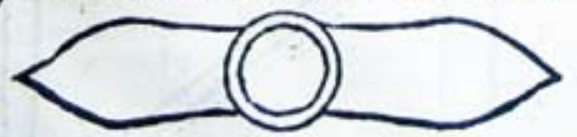

5

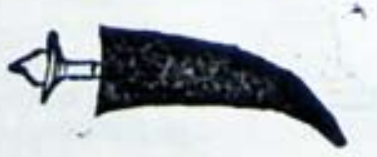

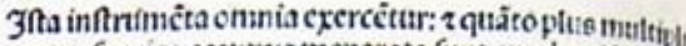
cantur fpecics cosums p:eparata funt opud artifice; of velocioz ad operationé fuam: zaltio apud boninco pro peer quatitatem fuam. " Tlon crgo oefpicice ereis in 0 mentum qutin fint apud tepreparata. Znexcufabilis eft cnim neceflitas cozum.

CDectractione fecundine. CAP. IXXVIII.

(2)

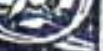

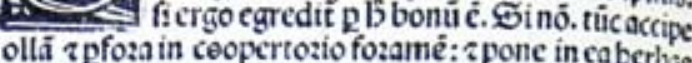
olla zproza in ceopertozio fozame: zpone in caberbas aperientes os matricis:ficut calamentú rutam: zanctí: z camomillaz: zf fcbä: zcaftia ligneã:zcentaureas.accipe omnco iftas berbastatit quafdas carum:z fubmergeces cum aqua: pone cam fuper ignes: ocindepone embula arundinis fuper fozamen coopertouy olle: z crtremitate aliam in os matricis: $z$ tencat cã oonec perneniat vapos ad concautatcm matricig. oeinde fac cam fternuture fi cut oiximug. fecundina cnis cgredictur cú facilitate. Ŝ autem remancatpoft banceuratione 5 non cgrcdiatur tunc paccipe obftetricivt fubmergat manum fua in olco fifamino:att mucillagincoltcc.ocide intromittat in vol uam: querat cum cafccundinam. Lum ergo inuenerit cantunc accipiat eã z cxtendat ipfam panlatim. Ëiat cem fucrit antexa in p:ofundo matricis:tunc intromit tat manum fm qó narratumtig. Donec quando inucne rit fecundinam zextrabat caz paulatim fre rectitudine: $v$ tnon cadat matrixapud attractionez vebemente; im mo opostct $v t$ permutecur cum facilitate ad Lateraoce tra $z$ finiftra.ocindeaddatur in quititatcs attractiontis 3pfacniz obedit:tunc eferuatur: zcuadit ab adberćtia. C. O: fiog matricis ctt co.rtacam ficut nosiamnarrs tumus:cura cam cum fternutationc: $z$ crmedicatiōe ol le cumberbis. Si ait non egredizur cum omnibuscue narraumus:tunc cauc ne fatigeris fupcr cam in iteratio ne extractionis. Clerū opoztet ve q̧ó egredicur ad osms triciserea liges ad coxîn mulicris. ocindeclifierijaem cum vnguenco tertrafarmacon. 3pluz enimputrefacict cam polt oics z oiffoluctur zegredicur. Zlerumtamen q̨uandoputrefit cleuarur cx ca odozmalus aditomací zcaput zleditillud infirmam. Dpoztet crgo vt admini frentur fufiumigationce conucnicntes ad illud. Quidj autem antiquozüiam experti funt fuffumigatione; ns, furcy a ficuum ficcarum. Sozma inftrumenti quo fufu migatur muticr apud retentionéfecundine zmenftruo rum. Siat ex vitro fife alcama:aut ex $z$ cre: 2 ponat́ extre mitas ampla fuper ignez: $z$ fuffumigatio fit pofica fuper psunas tencat cam oonec confumatur illa fufiumigatio z itcraaliam.

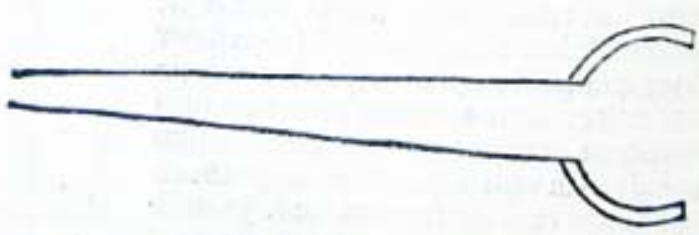

C¿̉ẹtratiōeani nöperfozati. CAP. IxxIx.

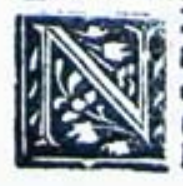
Żfcunť multipucrozuี z anicozü funt nópfo rati:quos ias opilauit fffac fubtile. Opsergo obftetrici vt pfozet illud fifac oigito fuo:th nō:perfozet î̀ en cü fpatumili acuto z caucas lacertü ne tangateü: Deindeponc fuper īivis

The obstetric instruments illustrated in Albucasis's surgical treatise first printed in 1500/0I, which is discussed in the article on pages 85-88. The text makes it clear that the instruments on the left are for use in extracting a dead fetus from the uterus and not to assist delivery of a live child. The illustrations are printed from wood blocks inserted in the forme of metal type and printed with the text in the same impression of the press. This book, the earliest illustrated printed book in the Sibbald Library, is a very early example of the embedding of illustrations in the text. The image above is on Lib. II Cap. LXXVII (folium 25 verso). 